2020

\title{
Rethink Everything 1: Markets, Globalization, Development
}

Nikhilesh Dholakia

University of Rhode Island

Deniz Atik

University of Texas Rio Grande Valley

Follow this and additional works at: https://digitalcommons.uri.edu/mgdr

Part of the Anthropology Commons, Economics Commons, Marketing Commons, Other Business Commons, and the Sociology Commons

\section{Recommended Citation}

Dholakia, Nikhilesh and Atik, Deniz (2020) "Rethink Everything 1: Markets, Globalization, Development," Markets, Globalization \& Development Review: Vol. 5: No. 1, Article 1.

DOI: 10.23860/MGDR-2020-05-01-01

Available at: https://digitalcommons.uri.edu/mgdr/vol5/iss1/1

This Editorial is brought to you for free and open access by DigitalCommons@URI. It has been accepted for inclusion in Markets, Globalization \& Development Review by an authorized editor of DigitalCommons@URI. For more information, please contact digitalcommons-group@uri.edu. 
Rethink Everything 1: Markets, Globalization, Development

\section{Markets, Globalization \& Development Review}
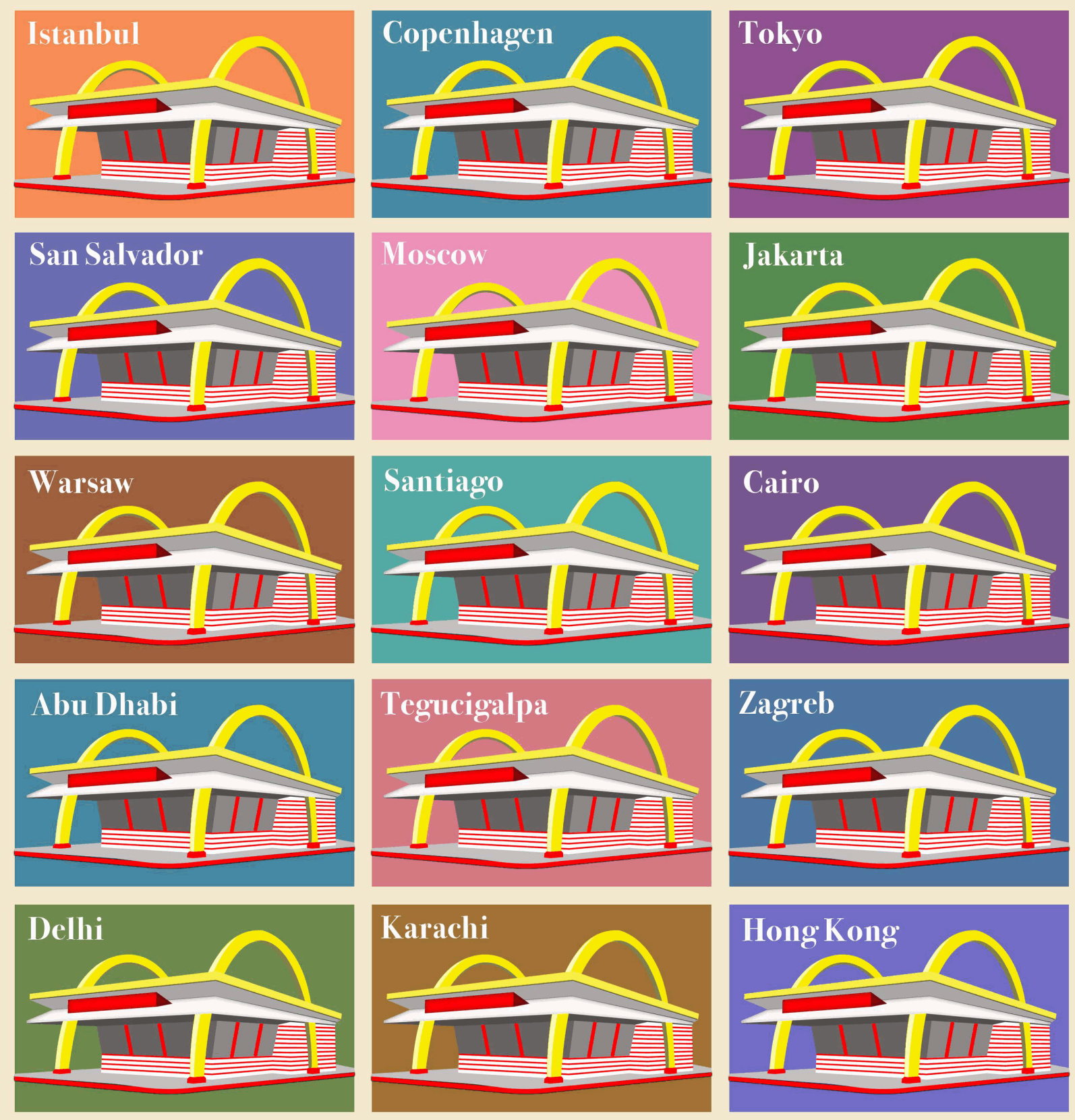

This editorial is available in Markets, Globalization \& Development Review: https://digitalcommons.uri.edu/mgdr/ vol5/iss $1 / 1$ 


\section{Rethink Everything 1: Markets, Globalization, Development}

\section{Introduction}

In 2020, while attempting to fight a deadly virus pandemic, the world changed on multiple dimensions. For this journal, all three elements in its title - markets, globalization and development - were jolted violently.

Many markets - travel, tourism, entertainment, and more - either shut down totally, for months, or were reduced to barebones levels, just to sustain some vitally essential services. Any commerce seen as discretionary and deferrable became just that - discretionary and deferrable. Even with gradual reopening, there were dire predictions things in the future would never revert to the way things were. And yet, even in these dire times, some markets - those that relied on virtual (Dholakia and Reyes 2013) and remote ways of doing things - entered a phase of explosive growth. Just five big American tech companies Microsoft, Apple, Amazon, Alphabet (Google) and Netflix - had market capitalization that reached nearly one-fifth of the capitalization of S\&P 500 stocks, a level of concentration not seen since the so-called 'dotcom' bubble of 2000 (Dholakia and Pandya 2007). In early June, for a while, Microsoft and Apple each became a \$1.5 trillion company. Then, in a few short months, Apple raced ahead to become the world's first $\$ 2$ trillion company. To put things in stark perspective, only about 12 countries out of about 250 in the world had annual GDP over $\$ 1.5$ trillion, and, in 2019, only 8 had GDP over $\$ 2$ trillion - a number that will shrink in 2020. Even more telling, in early June, the combined market value of the five tech firms just named became larger than the annual GDP of all but two countries - USA and China. So - even amidst the massive unemployment, long lines at food pantries, and struggling or shuttered Main Street businesses during this pandemic - showers of gold rained upon the investors in elite tech firms. The wealth of the miniscule population sliver known as the "billionaire class" shot up by about one-third, in just a few early months of the pandemic (Neate 2020). In short, pandemic markets ranged from dead, desperate, and dwindled in many service categories - to dazzlingly spectacular in other categories, such as technology stocks.

What about globalization, then? Precursor ideas to de-globalization, such as de-internationalization, have been around for a while (e.g., Benito and Welch 1997; Turcan 2003), but tucked away in small specialized corners of academic business literature. In 2020, such ideas entered the center stage of global media. Many news websites singled out 'de-globalization' as a topic of central interest to them. It can be expected that the scramble of academic studies on de-globalization 
and similar concepts is underway. As the pandemic entrenched globally, but also came under a modicum of control in some nations, globalization patterns began to stretch and shift, to some extent favoring the nations that had taken early actions and had managed to stanch the spread of the disease in significant ways. In particular, the post-World War II role of the United States - as the standard-bearer and orchestrator of globalization processes - experienced a significant shock, accelerating an already-happening decline.

While we see some seesaw aspects in markets and globalization - mostly down but some upswings - the picture is much darker regarding the third part of this journal's title, viz., development. The June 2020 assessment of the global economy from the World Bank was foreboding:

The COVID-19 pandemic has, with alarming speed, delivered a global economic shock of enormous magnitude, leading to steep recessions in many countries. The baseline forecast envisions a 5.2 percent contraction in global GDP in $2020-$ the deepest global recession in eight decades, despite unprecedented policy support... Despite [some strong policy] measures, per capita incomes in all [emerging and developing] regions are expected to contract in 2020, likely causing many millions to fall back into poverty (World Bank 2020, p. xv).

Unless concerted and cooperative international policy actions are taken, even before the pandemic is tackled, there could be no 'upswing' (and many painful downswings) on the development dimension. In the words of United Nations Deputy Secretary-General Amina Mohammed (UN News 2020):

I am extremely concerned. COVID-19 is a threat multiplier. We have a health emergency, a humanitarian emergency and now a development emergency. These emergencies are compounding existing inequalities. In advanced economies, we're seeing higher rates of mortality among already marginalized groups. And in developing countries, the crisis will hit vulnerable populations even harder.

\section{Contributions in this Issue}

In the midst of an unfolding crisis and tragedy, there are limits to social analysis and to incisive interpretation. The perspectives needed for distanced, detached viewing of phenomena are simply not there. For the MGDR authors in Issue 1 and Issue 2 of Volume 5, such limitations have been quite problematic. Hence, from an editorial standpoint, we 
encouraged publishing of pieces that employ provocative imagination, partially supportable by evidence and past scholarship. The reviewers of movies - of 'Contagion' in this issue (Ozgun 2020) and of 'Elysium' in the next issue (Ulusoy 2020) - were in a slightly better position because the moviemakers, at some points in the past, had exercised their provocative imaginations, and had produced works that partly foreshadowed contemporary events. Issue 1 of Volume 5 - this issue has one article, two challenging dialogue contributions, and one insightful film review. In Issue 2, we expect more dialogue contributions, and at least one film review - all of course attempting to relate to the 2020 COVID-19 pandemic.

The article by Cambefort (2020) does marshal some current secondary data-based evidence, to discusses in depth how the pandemic has challenged the global consumption practices. In particular, she puts emphasis on how COVID-19 acted as catalyst to downsize consumption, having consumers realize that many of their purchases may be unnecessary. According to the author, the pandemic provided an opportunity to test simpler lifestyles. She also stresses that the virus may bolster anti-globalization sentiment, leading consumers to prefer local brands over global ones, especially over Chinese brands since the virus originated in China. Furthermore, she suggests that consumers have been attentive to the possible misconduct of certain companies during the pandemic, grounding their decisions on the actions of such brands. Cambefort also presents Corona beer brand as an instance of incidental collateral damage - because of the name of the brand - of the pandemic, with decreasing sales of this beer for a while. Finally, she concludes by suggesting that some consumers may go back to their previous consumption habits once the pandemic is over; however, there is also a chance that the virus will act as a catalyst for reducing consumption over the long term.

Hong (2020) has a Dialogue piece that is crafted to provoke and promote rethinking along multiple dimensions. He makes a stark and bold opening that reveals how - through COVID-19 - we are now exposed more than ever. We are exposed biologically, economically, and socio-politically. First, the author puts emphasis on the involuntary idleness the pandemic brought about, because of being unemployed or working or schooling remotely. According to Hong, "Idleness as an anathema to neoliberalism used to entail disconnection and isolation, but it now can mean hyper-connectivity and hyper-activity, which are the very qualities the ideology promotes (p.3)." Second, he discusses the impacts of the augmented risks and uncertainty for the markets. Third, in the after-coronavirus (AC) markets, he argues that consumers will prefer more solidity rather than liquidity in social relations with "various kinds of support, compassion, and the fundamental sense of being, belonging, and believing (p.7)." This of course is a noble, sanguine view 
of the future - a view that faces the hurdle of overcoming a cruel, dark, conflict-ridden present. The author suggests that the only new normal, in a contemporary sense, is distrust and we need to re-positivize life in a new market society, including re-imagining the social. We hope that future contributions to MGDR would keep on suggesting new directions, as many MGDR issues have done in the past (see, e.g., Üçok and Houston 2018; Boje and Hillon 2017; Ozcan and Takayama 2019).

The second Dialogue contribution of this issue addresses an issue that has been frequently prominent in popular media as well as in scholarly explorations - the role of social media platforms in influencing our economic, political, and cultural lives (see, e.g., Orlowski 2020). In this Dialogue piece, Kwet (2020) draws the readers' attention to the increasing social media usage during the pandemic lockdown. First, he underlines the monopolistic power of centralized social media giants such as Facebook related to surveillance, censorship, and manipulation of consumers. Then, he discusses how some of the proposed solutions to fix social media do not work, one of them being the neo-Brandeisian solution. Neo-Brandeisians suggests that antitrust regulations will help to solve the problem by breaking up "companies into component parts and force social networks to interoperate (p.2)." Kwet argues, however, that increasing the number of competing and profit seeking social media companies will not create an equitable experience since the new entry firms can all spy on users and use their data for marketing purposes. According to the author, the end goal should be "to transform social media into a 'global commons' that is owned, controlled, and governed directly by the people (p.2)." He proposes digital socialism, a commons-based socialist solution and presents Fediverse - a decentralized collection of interoperable social media networks (such as Mastodon, PeerTube, and PixelFed) with already millions of users - as the alternative to the monopolies of Facebook, Google, Microsoft and Apple. Kwet states that "a free and open sourced, decentralized ecosystem is the only solution that can break up Big Social Media (p.7)." In future MGDR issues, we would be encouraging contributors to explore such alternative approaches.

\section{Media Review in this Issue}

The media review in this issue of MGDR is about the film 'Contagion', directed by Steven Soderbergh, that anticipated - years ago - many of the eventualities as well as the debates of the 2020 COVID-19 pandemic. Indeed, it is somewhat unnerving to watch this film in 2020, with the in-your-face appearance of institutional and national actors such as CDC, WHO, China, and more. The review author, Ozgun (2020) notices the amazing intersects between the events of this 2011 movie and the actualities happening during the Covid-19 pandemic of 2020 while he also discusses in depth the essential divergences. Ozgun 
suggests that the cinematographic and narrative devices Soderbergh uses works "towards creating a documentary-like filmic language, and sustain a sense of realism in the film (p.4)." He especially points at the systemic failures, the incapacity of social institutions in responding to the pandemic both in the movie and in real life of 2020. On the other hand, he explains the differences in today's reality, especially the inequality that the pandemic has crystalized, with certain people at the lower rungs of society experiencing more harm than those on top. Ozgun expands his discussion on the social body theoretically and points at another divergence between the movie and the reality. He shows through his discussion how the "conception of body has been transformed from an "affective vessel" to an "economic vessel" (p.6)" in today's pandemic. "People did not riot in panic as in Soderbergh's film. Instead, they rebelled against not being able to work, or not being able to conduct business, in a semi-orderly fashion (p.7)," Ozgun (2020) stresses, for governments and markets, pandemic appeared as a global economic crisis rather than a social and humanitarian crisis with massive number of deaths, sadly.

\section{Concluding Observations}

Past pandemics have - sometimes, but not always - altered the course of history (Bristow 2012, Snowden 2019). Some of these shifts have not only been dramatic but also ameliorative - paving the way for a more just, more humane, more harmonious social order. Some public observers are hoping that this pandemic will end exploitative capitalism (Mason 2020), while others are coming to the opposite conclusion noting emergent tendencies that could boost neoliberal technology-enabled giantism (Klein 2020). There is of course no way to foresee the future, or to 'back guess' - from a future vantage point - the history of this period.

At MGDR, we are finding that seismic shocks are affecting all three intellectual pillars of this journal: markets, globalization, and development. In foreshadowing the emerging future, the contributions that follow in this issue, and the next issue (Volume 5, Number 2) of MGDR, make a small start; and we hope the dialogues and discourses would continue to intensify and improve.

We want to conclude this introductory editorial essay with words from one of the most compassionate people on the planet, Pope Francis. We leave you with a long excerpt from these remarks - about the pandemic, the planet and the people - made by the pontiff:

This coronavirus crisis is affecting us all, rich and poor alike, and putting a spotlight on hypocrisy. I am worried by the hypocrisy of certain political personalities who speak of facing 
up to the crisis, of the problem of hunger in the world, but who in the meantime manufacture weapons.

This is a time to be converted from this kind of functional hypocrisy. It's a time for integrity. Either we are coherent with our beliefs or we lose everything.

Every crisis contains both danger and opportunity. Today I believe we have to slow down our rate of production and consumption and to learn to understand and contemplate the natural world. We need to reconnect with our real surroundings. This is the opportunity for conversion.

I see early signs of an economy that is more human. But let us not lose our memory once all this is past, let us not file it away and go back to where we were. This is the time to take the decisive step, to move from using and misusing nature to contemplating it. We have lost the contemplative dimension; we have to get it back.

And speaking of contemplation, l'd like to dwell on one point.

This is the moment to see the poor. Jesus says we will have the poor with us always, and it's true. They are a reality we cannot deny. But the poor are hidden, because poverty is bashful.

In Rome recently, in the midst of the quarantine, a policeman said to a man: "You can't be on the street, go home." The response was: "I have no home. I live in the street."

There is such a large number of people who are on the margins. And we don't see them, because poverty is bashful. They have become part of the landscape; they are things.

Mother Teresa saw them and had the courage to embark on a journey of conversion. To "see" the poor means to restore their humanity. They are not things, not garbage; they are people.

We can't settle for a welfare policy such as we have for rescued animals. which is how the poor are often treated. 


\section{References}

BBC News (2020), "Rethink: Pope Francis Warns Poor Have Become

Part of Landscape," BBC News, (accessed on September 7,

2020), [available at: https://www.bbc.com/news/world-53055220]

Benito, Gabriel RG and Lawrence S. Welch (1997), "De-internationalization," MIR: Management International Review, 37: Special Issue, 7-25. https://www.jstor.org/stable/40228430

Boje, David M. and Hillon, Yue Cai (2017), "The Fifth Epoch: Socio-Economic Approach to Sustainable Capitalism," Markets, Globalization \& Development Review, 2 (1), Article 2. https://doi.org/10.23860/MGDR-2017-02-01-02

Bristow, Nancy K. (2012), American Pandemic: Lost Worlds of the 1918 Influenza Pandemic, Oxford UK: Oxford University Press.

Cambefort, Marine (2020), "How the COVID-19 Pandemic is Challenging Consumption," Markets, Globalization \& Development Review, 5 (1), Article 2. https://doi.org/10.23860/MGDR-2020-05-01-02

Dholakia, Nikhilesh and Anil M. Pandya (2007), "Explaining Dotcom Failures: A Congestion Framework," International Journal of Electronic Business, $\quad 5 \quad$ (1), 22-41. https://doi.org/10.1504//JEB.2007.012289

Dholakia, Nikhilesh and lan Reyes (2013), "Virtuality as Place and Process," Journal of Marketing Management, 29 (13-14), 1580-91. https://doi.org/10.1080/0267257X.2013.834714

Hong, Soonkwan (2020), "'Coronated' Consumption in the Viral Market," Markets, Globalization \& Development Review, 5 (1), Article 3. https://doi.org/10.23860/MGDR-2020-05-01-03

Klein, Naomi (2020), "Screen New Deal," The Intercept, May 8, (accessed on June 21, 2020), [available at: https://theintercept.com/2020/05/08/andrew-cuomo-eric-schmidt -coronavirus-tech-shock-doctrine/]

Kwet, Michael (2020), "Fixing Social Media: Toward a Socialist Digital Commons," Markets, Globalization \& Development Review, 5 (1), Article 4. https://doi.org/10.23860/MGDR-2020-05-01-04 
Lakhani, Nina (2020), "Revealed: Millions of Americans Can't Afford Water as Bills Rise $80 \%$ in a Decade," The Guardian, (accessed on June 23, 2020), [available at:

https://www.theguardian.com/us-news/2020/jun/23/millions-of-a mericans-cant-afford-water-bills-rise]

Mason, Paul (2020), "Will Coronavirus Signal the End of Capitalism?," April 3, Al Jazeera, (accessed on June 21, 2020), [available at: https://www.aljazeera.com/indepth/opinion/coronavirus-signal-c apitalism-200330092216678.html]

Neate, Rupert (2020), "Wealth of US Billionaires Rises by Nearly a Third during the Pandemic," The Guardian, September 17, (accessed on September 20, 2020), [available at:

https://www.theguardian.com/business/2020/sep/17/wealth-of-u s-billionaires-rises-by-nearly-a-third-during-pandemic]

Orlowski, Jeff (2020), "We need to rethink social media before it's too late. We've accepted a Faustian Bargain", The Guardian, September 27, (accessed on September 27, 2020), [available at:

https://www.theguardian.com/commentisfree/2020/sep/27/socia I-dilemma-media-facebook-twitter-society]

Ozcan, Ahmet Can and Takayama, Yasuko (2019), "Thinking and Designing with Design Thinking," Markets, Globalization \& Development Review, 4 (2), Article 1. https://doi.org/10.23860/MGDR-2019-04-02-01

Ozgun, Aras (2018), "[Cntrl] + [Alt] + [Esc]? Virtual Platforms as Spaces of Control and Contestation," Markets, Globalization \& Development Review, 3, Article 1. https://doi.org/10.23860/MGDR-2018-03-03-01

Ozgun, Aras (2020), "Steven Soderbergh, Contagion (2011)," Markets, Globalization \& Development Review, 5 (1), Article 5. https://doi.org/10.23860/MGDR-2020-05-01-05

Snowden, Frank M. (2019), Epidemics and Society: From the Black Death to the Present, New Haven CT: Yale University Press. 
Turcan, Romeo V. (2003), "De-internationalization and the Small Firm," In Internationalization: Firm Strategies and Management, ed. Colin Wheeler, Frank McDonald and Irene Greaves, London: Palgrave Macmillan, Ch. 13, 208-22.

Ulusoy, Emre (2020), "Neill Blomkamp, Elysium (2013)," Markets, Globalization \& Development Review, 5 (2), forthcoming.

UN News (2020), "COVID-19 Pandemic Exposes Global 'Frailties and Inequalities': UN Deputy Chief," May 3, UN News, (accessed on September 16, 2020), [available at: https://news.un.org/en/story/2020/05/1063022]

Üçok Hughes, Mine and Houston, Rika (2018), "Introduction to the Special Issue: Alternative Imaginings," Markets, Globalization \& Development Review, 3 (2), Article 1. https://doi.org/10.23860/MGDR-2018-03-02-01

World Bank (2020), Global Economic Prospects, June 2020. Washington, DC: World Bank. License: Creative Commons $\begin{array}{lllll}\text { Attribution } & \text { CC } & \text { BY } & 3.0 & \text { IGO. }\end{array}$ https://doi.org/10.1596/978-1-4648-1553-9. 